\title{
Analisis Faktor Perilaku Konsumsi Remaja Terhadap Makanan Cepat Saji (Studi Aplikasi Social Cognitive Theory)
}

\author{
Nadhifa Salsabilla*¹, Muji Sulistyowati ${ }^{1}$ \\ ${ }^{1}$ Department of Health Promotion and Behavioral Science, Faculty of Public Health, \\ Universitas Airlangga, Indonesia
}

\begin{abstract}
Author's Email Correspondence (*): nadhifa.salsabilla-2016@fkm.unair.ac.id (+6282234574309)
\end{abstract}

\begin{abstract}
ABSTRAK
Konsumsi makanan cepat saji pada remaja dianggap sebagai hal sepele yang biasa dilakukan. Namun, dampak yang akan dirasakan berupa gangguan kesehatan dalam jangka waktu pendek maupun jangka panjang, seperti obesitas. Salah satu sekolah di Surabaya yang memiliki angka kejadian obesitas cukup tinggi yakni SMAN 2 Surabaya. Tujuan penelitian ini untuk menganalisis faktor perilaku yang berhubungan dengan konsumsi makanan cepat saji pada remaja menggunakan studi aplikasi Social Cognitive Theory. Penelitian ini merupakan penlitian observasional analitik dengan desain penelitian cross sectional. Populasi penelitian ini adalah siswa kelas X dan XI SMAN 2 Surabaya dengan penarikan sampel menggunakan stratified random sampling sebanyak 102 orang. Pengumpulan data menggunakan kuisioner yang dibagikan secara online. Variabel independen penelitian ini adalah karakteristik individu, self efficacy, pengetahuan, self regulation, dukungan keluarga, dukungan teman sebaya, dan paparan informasi. Sedangkan variabel dependen yaitu tindakan konsumsi makanan cepat saji pada remaja. Pengolahan dan analisis data menggunakan uji Kruskal Wallis. Hasil penelitian menunjukkan bahwa terdapat hubungan antara uang saku $(\mathrm{p}=0,015)$, self regulation $(\mathrm{p}=0,047)$, dan dukungan orangtua $(\mathrm{p}=$ $0,038)(p<0,05)$. Namun, pada variabel lainnya tidak terdapat hubungan dengan tindakan mengonsumsi makanan cepat saji. Penelitian ini diharapkan dapat memberikan kontribusi kepada pihak sekolah maupun Puskesmas setempat dalam melakukan pencegahan obesitas pada remaja.
\end{abstract}

Kata kunci: Remaja, Makanan cepat saji, Obesitas

Published by:

Tadulako University

Address:

Jl.Soekarno Hatta KM 9. Kota Palu, Sulawesi Tengah, Indonesia.

Phone: +628114120202

Email: Preventif.fkmuntad@gmail.com
Article history :

Received : 28012021

Received in revised form : 29022021

Accepted : 02022020

Available online 31122021 


\begin{abstract}
Consuming fast food on teenagers is considered something common to do. However, the effect that will be felt is in the form of short or even long term, like obesity. One of many schools in Surabaya has the high number of obesity such as SMAN 2 Surabaya. The objective of this research is to analyze the behaviour factors dealing with fast food consumption on teenagers using Social Cognitive Theory. This research used observational analytical research with cross sectional design. The population of this study were 10th and 11th grade in SMAN 2 Surabaya by using stratified random sampling for 102 people The data collection was done by questionnaire. The independent variable were individual characteristics, self efficacy, knowledge, self regulation, family support, friends support and information exposure. While the dependent variable was the fast food consumption on teenagers. The process and analysis of data were done by Kruskal Wallis test. The result of this research showed that the majority of teenager had fast food consumption with low chance. The result of Kruskal Wallis test shows that there are some connections among allowance, $(p=0,015)$, self regulation $(p=0,047)$, and family support $(p=0,038),(p<0,05)$. Yet, we found no connection among other variables with the fast food consumption. This research is expected to give contribution on school side or public health center to prevent obesity on teenagers.
\end{abstract}

Keywords : Teenagers, Fast Food, Obesity

\title{
PENDAHULUAN
}

Perkembangan berbagai macam penyakit di dunia terus meningkat pada semua kelompok usia, salah satunya Penyakit Tidak Menular (PTM). Penyakit Tidak Menular (PTM) disebut dengan penyakit kronis yang menjadi penyebab kematian tertinggi di dunia(1). Penyakit tidak menular tidak mengalamai proses penyebaran penyakit dari orang ke orang, melainkan disebabkan oleh adanya multifaktor yaitu factor genetik, fisiologis, lingkungan, dan perilaku.

Sekitar 41 juta orang (71\%) di dunia meninggal diakibatkan oleh PTM setiap tahunnya(1). Penyatkit tidak menular berhubungan dengan genetik, pengaruh lingkungan dan gaya hidup, seperti merokok, konsumsi alkohol diet yang buruk, kurangnya aktivitas(2). Salah satu penyakit dengan presentase tertinggi di dunia sebagai penyumbang kematian terbanyak yaitu diabetes $(7 \%)$.

Berdasarkan data hasil Kementrian Kesehatan RI tahun 2013 diketahui bahwa aspek kegemukan atau obesitas memiliki kontribusi terhadap diabetes(3). Ditinjau dari faktor risiko secara umum yang menyebabkan terjadinya diabetes yaitu obesitas, pola makan yang buruk, dan rendahnya aktivitas fisik(4).

Obesitas didefinisikan sebagai akumulasi lemak abnormal atau berlebihan dalam tubuh yang mampu menimbulkan gangguan kesehatan(1). Obesitas terjadi karena akibat 
ketidakseimbangan asupan energi (energy intake) dengan energi yang digunakan (energy expenditure) dalam waktu yang lama yang dapat diukur oleh satuan hitung yakni Body Mass Index (BMI). Obesitas saat ini menjadi permasalahan dunia bahkan WHO mendeklarasikan sebagai epidemic global(1). Data menyatakan bahwa prevalensi obesitas dan kelebihan berat badan (overweight) di kalangan anak-anak dan remaja berusia 5 - 19 tahun meningkat secara drastis dari 4\% pada tahun 1975 hingga menjadi lebih dari 18\% pada tahun 2016(1).

Jumlah populasi remaja di Indonesia sangat besar. Berdasarkan Survei Penduduk tahun 2010 remaja yang berusia 15 - 24 tahun memiliki presentase sebesar $20 \%$ dari seluruh penduduk di Indonesia yaitu 237,6 juta jiwa(6). Proyeksi data dari Badan Pusat Statistik (BPS) tahun 2017 menunjukkan jumlah populasi remaja di Indonesia meningkat menjadi $43,5 \%(6)$.

Menurut Peraturan Menteri Kesehatan RI Nomor 25 Tahun 2014 menyatakan bahwa remaja merupakan penduduk dalam rentang usia 10-18 tahun(7). Masa remaja adalah periode pertumbuhan paling cepat kedua setelah masa kanak-kanak(8). Usia remaja merupakan periode rentan gizi karena berbagai sebab yaitu karena usia tersebut memerlukan zat gizi yang lebih tinggi karena adanya pertumbuhan fisik. Selain itu, pada usia remaja cenderung terjadi perubahan gaya hidup dan kebiasaan makan. Akibat perubahan kondisi secara fisik dan mental, cenderung mengakibatkan pola pikir dan emosi yang belum stabil dalam menentukan suatu perilaku, terutama dalam perilaku sehat.

Indonesia merupakan salah satu negara berkembang yang memiliki presentase obesitas pada remaja yang tinggi dan terus mengalami kenaikan. Berdasarkan data Kementrian Kesehatan RI tahun 2018 remaja obesitas pada tahun 2007 sebesar 18,8\% dan meningkat hingga $31 \%$ pada tahun 2018. Obesitas paling banyak terjadi di perkotaan dibanding di pedesaan dengan persentase $38,3 \%$ di perkotaan (urban) dan $28,2 \%$ di pedesaan (rural)(9). Salah satu provinsi di Indonesia yaitu Jawa Timur menunjukkan data prevalensi sangat gemuk lima belas provinsi terbanyak yaitu sebesar dari 30,38\% angka prevalensi nasional(1) .

Salah satu penelitian lain yang dilakukan pada 50 orang menyatakan bahwa terdapat 49 orang remaja (98\%) mengalami obesitas karena pola makan yang buruk(11). Pola makan yang

dimaksud yaitu pola makan yang buruk yang disebabkan karena jumlah asupan energi yang berlebih dan jenis makanan dengan kepadatan kalori yang tinggi dan mampu menyebabkan ketidakseimbangan energi (10). 
Pergeseran konsep makan bangsa Indonesia merupakan contoh konkret dampak adanya pengaruh budaya asing yang masuk ke dalam tubuh bangsa Indonesia. Salah satu bentuk pergeseran konsep makan yaitu menjamurnya makanan cepat saji (fast food) di Indonesia(12)

- Berdasarkan data penelitian yang dilakukan di Brebes menyatakan bahwa frekuensi konsumsi makanan cepat saji selama 1 minggu, anak yang obesitas lebih banyak mengonsumsi makanan cepat saji, yaitu dengan frekuensi lebih dari 2 kali seminggu(8). Hal tersebut juga dipertegas dengan penelitian yang dilakukan oleh Badjeber yang menunjukkan bahwa sisa-siswi yang sering mengonsumsi makanan cepat saji $>2 \mathrm{kali} /$ minggu memiliki risiko 3,28 kali terkena obesitas (10) .

Berdasarkan data Profil Kesehatan Surabaya tahun 2018 terkait pemeriksaan obesitas pada remaja dengan usia $\geq 15$ tahun menunjukkan bahwa sebesar 15,51\% atau sekitar 163.036 penduduk Surabaya mengalami obesitas(11). Kecamatan Genteng, Kelurahan Ketabang merupakan salah satu wilayah yang ada di Surabaya yang memiliki angka persentase kejadian obesitas yang paling tinggi dan mengalami peningkatan yaitu pada tahun 2017 (47,64\%) hingga pada tahun 2018 (57,05\%). Penliti melakukan studi pendahuluan yang dilakukan pada bulan Juni 2020 di SMAN 2 Surabaya yang terdiri dari siswa kelas X dan XI melalui survei dan wawancara secara online. Mayoritas siswa SMAN 2 Surabaya menjawab mengenai alasan mengonsumsi makanan cepat saji, yaitu

"karena praktis aja dan bikin nagih pengen makan lagi" AP.

"biasanya sering dikonsumsi buat makanan apalagi kalau laper di tengah malam dan di rumah nggak ada makanan yang akhirnya bikin mie instan atau pesan fried chicken" HS.

"karena rasanya yang enak, tapi sekarang jarang konsumsi fast food karena mama sering masak di rumah" AD. Melalui latar belakang dan observasi awal yang telah diuraikan peneliti, dapat menggambarkan bahwa makanan cepat saji masih menjadi pilihan yang menarik bagi remaja untuk dikonsumsi. Tujuan penelitian ini adalah untuk mengetahui faktor perilaku apa saja yang berhubungan dengan konsumsi makanan cepat saji pada remaja di SMAN 2 Surabaya.

Aplikasi Social Cognitive Theory memiliki konsep yang sesuai dengan topik penelitian. Konsep tersebut yaitu reciprocal determism yang memiliki makna bahwa perilaku manusia dan lingkungan berinteraksi serta mempengaruhi satu sama lain yang mengarah pada suatu perubahan perilaku, termasuk perilaku makan itu sendiri(13). Teori ini merupakan salah satu 
teori dengan pendekatan secara interpersonal untuk mendapatkan gambaran individu dalam berperilaku yang dilihat melalui faktor personal dan faktor lingkungan(14). Model pengaplikasian teori tersebut mampu memberikan gambaran yang komperhensif mengenai faktor penentu perilaku baik dari segi internal maupun eksternal.

Berdasarkan hal tersebut perlu dilakukan penelitian lebih lanjut mengenai faktor-faktor yang mempengaruhi remaja dalam perilaku mengonsumsi makanan cepat saji menggunakan pendekatan Social Cognitive Theory. Penelitian ini akan menganalisis beberapa faktor yaitu faktor personal yang meliputi self efficacy, pengetahuan, dan self regulation. Faktor lingkungan meliputi dukungan keluarga, dukungan teman sebaya, dan paparan informasi.

\section{METODE}

Penelitian ini menggunakan jenis penelitian observasional analitik dengan desain penelitian cross sectional. Objek penelitian ini adalah siswa SMAN 2 Surabaya. Populasi dalam penelitian ini yaitu siswa kelas $X$ dan XI di SMAN 2 Surabaya dengan penarikan sampel menggunakan stratified random sampling dari sebanyak 102 orang yang sesuai dengan kriteria. Peneliti menggunakan pendekatan kuantitatif dalam melaksanakan penelitiannya.

Penelitian ini dilaksanakan kurun waktu selama dua bulan, yaitu Juli 2020 hingga September 2020. Sumber data penelitian ini terdiri dari data primer dan sekunder. Data primer didapatkan melalui kuesioner online yang dibagikan kepada responden yaitu siswa kelas $\mathrm{X}$ dan kelas XI SMAN 2 Surabaya. Data sekunder didapatkan melalui Profil Sekolah SMAN 2 Surabaya, Data Riskesdas tahun 2013 - 2018 mengenai obesitas remaja, Profil Kesehatan Surabaya tahun 2018, serta data lainnya terkait kejadian obesitas pada remaja.

Penelitian ini telah mendapat surat keterangan kelayakan dari Komisi Etik Penelitian Kesehatan Fakultas Keperawatan Universitas Airlangga Surabaya yang bernomorkan 2078KEPK. Analisis statistik menggunakan aplikasi SPSS (Statistical Package for the Social Sciences) menggunakan uji Kruskal Wallis untuk melihat hubungan antara varibel usia, kelas, uang saku, self efficacy, pengetahuan, self regulation, dukungan teman, dukungan orangtua, dan paparan informasi dengan tindakan mengonsumsi makanan cepat saji.

\section{HASIL}

Hasil penelitian yang dilakukan menjelaskan gambaran karakteristik responden yang meliputi usia, kelas, dan jumlah uang saku dalam satu bulan. 


\section{Karakteristik Responden}

Tabel 1.

Distribusi Berdasarkan Karakteristik Responden di SMAN 2 Surabaya tahun 2020

\section{Variabel}

n

\section{Usia}

15 tahun

38

56

8

17 tahun

Jenis Kelamin

Laki-laki

Perempuan

Kelas

Kelas X

Kelas XI

Berat Badan (kg)

$40-50 \mathrm{~kg}$

$51-60 \mathrm{~kg}$

$61-70 \mathrm{~kg}$

$>70 \mathrm{~kg}$

Tinggi Badan

$<150 \mathrm{~cm}$

$150-160 \mathrm{~cm}$

$161-171 \mathrm{~cm}$

$>171 \mathrm{~cm}$

Uang Saku

$<500.000$

500.000-1.000.000
34

68

33,3

66,7

50

49,0

52

51,0

44

37

13

8

43,1

36,2

12,7

8,0

22,0

$49 \quad 48,0$

$40 \quad 39,2$

$11 \quad 10,8$

62

60,8

40
37,2

55,0

7,8

Sumber : Data Primer, 2020

Umur responden bervariasi pada rentang usia 15-17 tahun. Berdasarkan tabel 1, mayoritas usia responden yaitu pada usia 16 tahun sebesar 55,0\% dari total seluruh responden sebanyak 102 siswa.

Jenis kelamin responden di SMAN 2 Surabaya yang paling banyak adalah perempuan yaitu sebanyak 68 siswa $(66,7 \%)$. Hal ini sesuai dengan frekuensi total siswa berjenis kelamin perempuan lebih banyak di SMAN 2 Surabaya. Mayoritas responden adalah siswa kelas XI yaitu berjumlah 52 siswa $(51,0 \%)$.

Berdasarkan berat badan dan tinggi badan responden di SMAN 2 Surabaya, Mayoritas responden memiliki berat badan antara 40 - $50 \mathrm{~kg}$ dengan persentase sebesar $43,1 \%$.

Mayoritas responden memiliki tinggi badan antara $150-160 \mathrm{~cm}$ dengan persentase sebesar $48,0 \%$. 
Berdasarkan uang saku responden dalam satu bulan, diketahui bahwa mayoritas responden memiliki uang saku $<$ Rp500.000 (60,8\%).

Distribusi tingkat pengetahuan sebagai berikut:

\section{Tabel 2}

Distribusi Faktor Berdasarkan Social Cognitive Theory pada Responden di SMAN 2 Surabaya Tahun 2020

\begin{tabular}{lcc}
\hline \multicolumn{1}{c}{ Variabel } & n & $\%$ \\
\hline Tingkat Pengetahuan & 99 & 97,1 \\
Tinggi & 3 & 2,9 \\
Sedang & & \\
Tingkat Self Regulation & 2 & 2,0 \\
Tinggi & 84 & 82,4 \\
Sedang & 16 & 15,7 \\
Rendah & & \\
Dukungan Teman & 60 & 58,8 \\
Baik & 36 & 35,3 \\
Cukup baik & 6 & 5,9 \\
Buruk & & \\
Dukungan Keluarga & 68 & 66,7 \\
Baik & 31 & 30,4 \\
Cukup baik & 3 & 2,9 \\
Buruk & & \\
Paparan Informasi & 95 & 93,1 \\
Baik & 7 & 6,9 \\
Cukup baik & &
\end{tabular}

Sumber : Data Primer, 2020

Berdasarkan tabel 2, mayoritas tingkat pengetahuan responden tinggi yaitu sebesar 97,1\%. Melalui data tersebut menunjukkan bahwa mayoritas responden di SMAN 2 Surabaya menjawab pertanyaan pada lembar kuisioner dengan tepat dan benar.

Mayoritas responden memiliki self regulation dengan tingkat sedang $(82,4 \%)$. Hal tersebut menunjukkan bahwa masih terdapat kekurangan dalam mengontrol diri dalam melakukan tindakan. Selain itu juga menunjukkan bahwa banyak responden mengonsumsi makanan cepat saji tanpa memikirkan dampaknya terlebih dahulu. Alasan mayoritas responden tidak membatasi konsumsi makanan cepat saji diantaranya karena citra rasa menu yang disajikan membuat ingin terus membelinya. Faktor yang memicu diantaranya seperti rasa ingin mengonsumsi makanan cepat saji yang sangat tinggi, informasi yang menarik mengenai fast food, dan lain sebagainya 
Mayoritas responden memiliki dukungan teman yang baik dengan presentase sebesar 58,8\%. Namun dukungan yang baik dari teman juga tidak menutup kemungkinan para remaja tetap mengonsumsi makanan cepat saji. Mengingat tingginya kepadatan aktivitas remaja usia sekolah yang cukup tinggi seperti ekstrakulikuler atau bimbingan di luar sekolah, mampu menyebabkan pemilihan makanan tidak lagi didasarkan pada kandungan gizi, tetapi hanya sekedar bersosialis asi untuk kesenangan agar tidak merasa kehilangan status(16).

Mayoritas responden mendapatkan dukungan baik dari orangtua yaitu sebesar $66,7 \%$. Dukungan tersebut dapat berupa wawasan mengenai kesehatan serta pengaturan menu harian anak. Harapannya melalui dukungan baik dari orangtua mampu memberikan arahan dalam menentukan perilaku yang baik, salah satunya yaitu meminimalisir konsumsi makanan cepat saji dan mengontrol uang saku anak.

Diketahui bahwa mayoritas responden mendapatkan paparan informasi yang baik yaitu dengan persentase sebesar 93,1\%. Informasi yang dimaksud yaitu informasi seputar kesehatan terutama mengenai kesehatan gizi. Melalui paparan informasi yang diperoleh responden diharapkan dapat memberikan wawasan untuk melakukan pencegahan dini agar terhindar dari penyakit tidak menular di usia muda.

Distribusi self efficacy responden sebagai berikut:

Tabel 3

Distribusi Berdasarkan Self Efficacy Responden di SMAN 2 Surabaya Tahun 2020

\begin{tabular}{ccc}
\hline \multicolumn{2}{c}{ Distribusi Berdasarkan Self Efficacy } & Responden di SMAN 2 Surabaya Tahun 2020 \\
\hline Variabel & Mean (95\% CI) & SD \\
\hline Selficacy & 4,71 & 1,05
\end{tabular}

Sumber: Data Primer, 2020

Berdasarkan table 6, nilai rerata (mean) memiliki angka yang cukup besar. Dapat diketahui melalui hasil rerata atau mean yang menunjukkan angka 4,71. Pernyataan pada pengukuran self efficacy penelitian ini adalah unfavorable. Rerata atau mean menunjukkan suatu pemusatan respon. Nilai rerata yang semakin mendekati kutub kata sifat akan menunjukkan respon subjek yang lebih mendukung kutub tersebut(15). Jika hasil yang diperoleh positif yaitu 4,71 maka menunjukkan bahwa mayoritas responden memiliki tingkat self efficacy yang rendah. 
Tabel 4

Distribusi Frekuensi Konsumsi Makanan Cepat Saji Remaja Sebelum Pandemi (Masa Aktif Sekolah) dan Selama Pandemi (Pembelajaran Online)

\begin{tabular}{|c|c|c|c|}
\hline Konsumsi Sebelum Pandemi & 2-7x/minggu & $3-4 x / b l n$ & $0-2 x / b l n$ \\
\hline Makanan & $\mathbf{n}$ & $\mathbf{n}$ & $\mathbf{n}$ \\
\hline Ayam goreng & 8 & 32 & 62 \\
\hline Burger & 0 & 19 & 83 \\
\hline Pizza & 0 & 11 & 91 \\
\hline Spaghetti & 1 & 19 & 82 \\
\hline Sosis & 14 & 34 & 54 \\
\hline Nugget & 15 & 34 & 53 \\
\hline French fries & 11 & 38 & 53 \\
\hline Onion rings & 3 & 14 & 85 \\
\hline Donat & 5 & 37 & 60 \\
\hline Bakso & 12 & 36 & 54 \\
\hline Spring roll & 9 & 21 & 72 \\
\hline Mie instant & 23 & 53 & 26 \\
\hline Gorengan & 17 & 44 & 41 \\
\hline Asinan & 4 & 12 & 86 \\
\hline Makanan kalengan & 3 & 10 & 89 \\
\hline
\end{tabular}

\begin{tabular}{lccc}
\hline Konsumsi Selama Pandemi & $\mathbf{2 - 7 x} / \mathbf{m i n g g u}$ & $\mathbf{3 - 4 x} / \mathbf{b l n}$ & $\mathbf{0 - 2 x} / \mathbf{b l n}$ \\
\hline Makanan & $\mathbf{n}$ & $\mathbf{n}$ & $\mathbf{n}$ \\
\hline \hline Ayam goreng & 10 & 43 & 49 \\
Burger & 3 & 29 & 70 \\
Pizza & 3 & 27 & 72 \\
Spaghetti & 4 & 17 & 81 \\
Sosis & 14 & 42 & 46 \\
Nugget & 15 & 44 & 43 \\
French fries & 16 & 26 & 50 \\
Onion rings & 5 & 8 & 89 \\
Donat & 10 & 28 & 64 \\
Bakso & 8 & 32 & 62 \\
Spring roll & 10 & 27 & 65 \\
Mie instant & 24 & 54 & 24 \\
Gorengan & 21 & 46 & 35 \\
Asinan & 5 & 9 & 88 \\
Makanan kalengan & 3 & 12 & 87 \\
\hline
\end{tabular}


Berdasarkan tabel 4 dapat diketahui bahwa mayoritas responden masih sering mengonsumsi jenis makanan cepat saji yaitu sekitar $>2$ kali dalam satu minggu pada saat masih aktif sekolah (sebelum pandemic). Tabel pertama tersebut menunjukkan frekuensi konsumsi makanan cepat saji pada saat responden masih aktif mengikuti proses mengajar di sekolah (sebelum terjadinya pandemi) yang berarti bahwa repsonden masih memiliki aktivitas yang cukup padat baik pada saat sekolah atau di luar jam sekolah.

Jenis makanan cepat saji yang paling sering dikonsumsi adalah mie instan, yaitu sebanyak 23 responden. Kemudian jenis gorengan juga masih menjadi favorit responden, mengingat cara penyajiannya yang cukup praktis dan dapat dikonsumsi kapan saja.

Kemudian berdasarkan tabel kedua pada Tabel 4 dapat diketahui bahwa mayoritas responden masih sering mengonsumsi jenis makanan cepat saji yaitu sekitar >2 kali dalam satu minggu. Tabel kedua tersebut menunjukkan frekuensi konsumsi makanan cepat saji pada saat masa pandemi yang berarti bahwa proses pembelajaran dilakukan secara online di rumah. Berkurangnya aktivitas di sekolah tidak mempengaruhi pola konsumsi responden untuk tetap mengonsumsi makanan cepat saji.

Seperti hasil pada tabel sebelumnya, tabel kedua menunjukkan bahwa jenis makanan cepat saji yang sering dikonsumsi adalah mie instan, yaitu sebanyak 24 responden. Kemudian jenis makanan gorengan juga masih menjadi favorit bagi responden untuk menemani aktivitas yang dilakukan di rumah.

\section{PEMBAHASAN}

Berdasarkan hasil penelitian, pembahasan ini peneliti akan mengagambarkan gambaran karakteristik responden, yang meliputi usia, kelas, tinggi badan dan berat bedan, serta uang saku yang diterima dalam satu bulan. Variabel lainnya yaitu tingkat pengetahuan, self efficacy, self regulation, dukungan teman, dukungan orangtua, dan ketersediaan paparan informasi.

\section{Menganalisis Karakteristik Responden}

Karakteristik responden pada penilitian ini meliputi usia, jenis kelamin, dan kelas responden. Penelitian ini melibatkan sebanyak 102 responden di SMAN 2 Surabaya. Usia responden berada pada rentang usia 15 - 17 tahun. Menurut uji statistic menunjukkan hasil $p$ value $=0,435$ yang berarti bahwa variabel usia tidak memiliki hubungan dengan tindakan mengonsumsi makanan cepat saji. 
Dapat dilihat dari penelitian yang dilakukan di Balikpapan menyatakan bahwa remaja berumur 15 - 17 tahun sering mengonsumsi makanan cepat saji. Namun hasilnya menunjukkan bahwa kebiasaan mengonsumsi makanan cepat saji memiliki hubungan yang lemah dengan variabel usia(16). Walaupun hasil penelitian tersebut tidak menunjukkan adanya hubungan pada variabel usia, akan tetap diperhatikan. Mengingat bahwa memasuki usia remaja seringkali dinilai sebagai masa-masa dengan tingkat emosional yang tidak menetu dan rasa ingin tahu yang tinggi dapat mendorong remaja untuk melakukan hal-hal yang diinginkan tanpa memikirkan dampaknya terlebih dahulu. Mayoritas responden berjenis kelamin perempuan. Hal tersebut sesuai dengan Data Pokok Pendidikan siswa di SMAN 2 Surabaya yang menyebutkan bahwa jumlah siswa perempuan lebih banyak disbanding siswa laki-laki.

Ditinjau dari variabel tinggi badan dan berat badang, mayoritas responden di SMAN 2 Surabaya memiliki tinggi bada sekitar $150-160 \mathrm{~cm}$. Kemudian dengan mayoritas berat badan sekitar 51 - $60 \mathrm{~kg}$. Jika dilihat sekilas, proporsi tinggi badan dan berat badan mayoritas responden dapat dikatakan tidak mengalami obesitas jika diukur menggunakan rumus Body Mass Index (BMI). Namun, faktanya masih terdapat responden yang memiliki berat badan lebih dari $70 \mathrm{~kg}$ sebanyak 8 responden. Hasil uji penelitian menunjukkan nilai $p$ value $=0,673$ pada variabel berat badan dan $p$ value $=0,840$ pada variable tinggi badan. Hal tersebut berarti bahwa kedua variabel tersebut tidak memiliki hubungan baik dengan tindakan mengonsumsi makanan cepat saji.

Sebagian responden memiliki jumlah uang saku sekitar Rp500.000 dalam satu bulan dengan presentase sebesar 60,8\%. Meskipun mayoritas jumlah uang saku per bulan responden berada dalam kategori rendah, namun tidak mempengaruhi daya beli responden terhadap makanan cepat saji. Hal ini seseai dengan pendapat Berg (1986) yang menyatakan bahwa orang biasanya membelanjakan sebagian pendapatan untuk makan.

Berdasarkan hasil uji penelitian menunjukkan nilai $p$ value $=0,0135$ pada variabel uang saku. Hal tersebut menunjukkan bahwa terdapat hubungan antara uang saku dengan tindakan mengonsumsi makanan cepat saji. Uang saku mempengaruhi makananan yang dikonsumsi dan mampu mempermudah untuk membeli suatu makanan(16). 


\section{Menganalisis Hubungan Tingkat Pengetahuan dengan Tindakan Mengonsumsi Makanan Cepat Saji}

Pengetahuan menjadi faktor dominan yang penting dalam membentuk tindakan atau perilaku seseorang(17). Pengetahuan yang dimiliki seseorang mampu mendorong kesadaran serta pemahaman terkait perilaku, khususnya perilaku makan.

Berdasarkan hasil penelitian menunjukkan bahwa sebagian besar responden memiliki tingkat pengetahuan yang tinggi. Mayoritas responden sudah mengerti bahwa konsumsi makanan cepat saji >2 kali dalam seminggu mampu memicu obesitas. Mereka juga paham bahwa obesitas yang terjadi pada remaja tidak hanya disebabkan oleh pola konsumsi yang buruk saja, melainkan beberapa faktor lain, seperti minimnya aktivitas fisik, manajemen stress yang kurang baik, pola tidur yang buruk, atau fajtor genetik.

Hasil uji statistik menunjukkan nilai $p$ value $=0,345$ pada variabel pengetahuan, yang berarti bahwa tidak adanya hubungan antara pengetahuan dengan tindakan mengonsumsi makanan cepat saji. Salah satu penelitian menyebutkan hal serupa, bahwa pengetahuan remaja tentang risiko obesitas belum tentu menghasilkan perilaku yang konsekuen(21). Semakin tinggi tingkat pengetahuan remaja, belum tentu akan memiliki perilaku konsumsi yang baik dan begitu pula sebaliknya.

\section{Menganalisis Hubungan Self Efficacy dengan Tindakan Mengonsumsi Makanan Cepat Saji}

Sikap sebagai manifestasi reaksi atau respon yang masih tertutup dari individu terhadap suatu stimulus atau objek yang ada dihadapannya. Reaksi atau respon tersebut terbentuk dari adanya interaksi sosial yang dialami setiap individu. Interaksi yang terjadi mampu mempengaruhi individu satu dengan lainnya, sehingga dapat membentuk pola sikap terhadap suatu objek(15). Salah satu sikap yang dimiliki individu yaitu self efficacy yang dimaknai sebagai keyakinan seseorang atas kapasitas dan kemampuannya untuk melakukan tindakan yang mengarah pada suatu hasil yang diinginkan(19).

Berdasarkan hasil penelitian menunjukkan bahwa tingkat self efficacy responden tergolong rendah, yang berarti bahwa mayoritas remaja masih kurang memiliki keyakinan untuk mengendalikan pola makan mereka, terutama terkait makanan cepat saji. Hasil uji statistik menunjukkan nilai $p$ value $=0,765$ yang berarti bahwa tidak ada hubungan antara self efficacy dengan tindakan mengonsumsi makanan cepat saji. 


\section{Menganalisis Hubungan Self Regulation dengan Tindakan Mengonsumsi Makanan Cepat Saji}

Self Regulation atau regulasi diri dapat diartikan sebagai kemampuan diri untuk merencanakan, mengarahkan, dan memonitori suatu perilaku untuk mencapai tujuan tertentu dengan melibatkan unsur fisik, kognitif, emosional, dan sosial.

Remaja dengan pengetahuan gizi yang baik maupun sedang, keduanya memiliki kebiasaan mengonsumsi fast food (16). Hal ini disebabkan karena fast food menjadi hal yang popular di kalangan remaja karena mampu menyajikan hidangans ecara praktis, cepat, dan menggugah selera makan.

Hasil penelitian menunjukkan bahwa tingkat self regulation responden dalam kategori sedang. Uji Statistik menunjukkan nilai $p$ value $=0,047$ yang berarti bahwa adanya hubungan antara self regulation dengan tindakan mengonsumsi makanan cepat saji.

\section{Menganalisis Hubungan Dukungan Teman dengan Tindakan Mengonsumsi Makanan Cepat Saji}

Pola perilaku yang dilakukan setiap individu bergantung pada kondisi lingkungan yang ada di sekitar individu itu sendiri. Memasuki usia remaja, seseorang akan lebih banyak menghabiskan waktu di luar rumah bersama dengan teman sebayanya dibandingkan dengan orangtua(20). Aktivitas yang bayak dilakukan di luar rumah membuat seorang remaja sering mendapat pengaruh dari rekan sebayanya(21).

Hal tersebut juga terjadi pada remaja usia sekolah yang memiliki kegiatan padat baik saat sekolah ataupun di luar jam sekolah. Kegiatan remaja yang padat mampu menyebabkan pemilihan makanan tidak lagi didasarkan pada kandungan gizi melainkan hanya sekesar bersosialisasi untuk kesenangan agar tidak merasa hilang status(16).

Hasil uji statistik menunjukkan nilai $p$ value $=0,496$ yang berarti bahwa variable dukungan teman tidak memiliki hubungan dengan tindakan mengonsumsi makanan cepat saji. Berdasarkan penelitian menunjukkan mayoritas responden mendpaat dukungan baik dari teman. Namn dukungan baik dari teman juga memiliki potensi yang tinggi untuk tetap mengonsumsi makanan cepat saji. Hal ini dapat terjadi karena ada beberapa faktor lainnya yang berasalah dari individu itu, seperti uang saku, self regulation dan lain sebagainya.

\section{Menganalisis Dukungan Orangtua dengan Tindakan Mengonsumsi Makana Cepat Saji}

Orangtua berperan penting dalam proses tumbuh kembang anak, terutama dalam hal mengarahkan anak untuk dapat menghadapi segala bentuk perubahan yang terjadi. Masa remaja, menjadi fase dimana anak mengalami peralihan dari fase anak-anak menjadi dewasa, 
sehingga seringkali terjadi perubahan gaya hidup, pola pikir, tingkat emosional, dan cara pandang terhadap sesuatu, seperti halnya pola makan.

Hasil penelitian menunjukkan mayoritas responden mendapatkan dukungan yang baik dari orangtua. Uji statistik menunjukkan nilai $p$ value $=0,038$ yang berarti bahwa terdapat hubungan antara dukungan orangtua dengan tindakan mengonsumsi makanan cepat saji.

Mengingat usia remaja (10-18 tahun) termasuk dalam periode rentan gizi karena memerlukan zat gizi lebih tinggi sebab adanya peningkatan pertumbuhan fisik, perubahan gaya hidup dan kebiasaan makanm serta kebutuhan khusus karena tingginya aktivitas di sekolah maupun di luar sekolah(22). Dukungan orangtua bagi remaja menjadi sangat penting terutama dalam membentuk pola hidup yang baik. Dukungan tersebut dapat diberikan melalui pengaturan menu makan anak, memperhatikan pemberian uang saku agar tidak berlebihan dan dibelanjakan jajan yang tidak sehat, serta membatas konsumsi makanan cepat saji.

\section{Menganalisis Hubungan Paparan Informasi dengan Tindakan Mengonsumsi Makanan Cepat Saji}

Berbagai media memiliki dampak yang cukup besar terhadap seseorang, baik media online maupun media offline. Perkembangan teknologi yang sangat pesat membuat para remaja dengan mudah mengakses informasi mengenai hal baru di sekitarnya, tak terkecuali terkait tren konsumsi makanan cepat saji.

Tren makanan di kalangan remaja adalah makanan cepat saji dibandingkan dengan makanan tradisional. Perubahan teknologi, tingkat social ekonomi, dan factor budaya menyebabkan perubahan pola makan yang cenderung mengonsumsi makanan cepat saji(23).

Berdasarkan uji statistik menunjukkan nilai nilai $p$ value $=0,803$ yang berarti bahwa tidak adanya hubungan antara paparan informasi dengan tindakan mengonsumsi makanan cepat saji. Meskipun begitu tidak menutup kemungkinan bahwa media yang beredar di social media atau media cetak lainnya memiliki daya Tarik tersendiri bagi konsumennya, terutama remaja. Mengingat para remaja memiliki uang saku, sehingga hal ini dimanfaatkan oleh penunjang iklan suatu produk makanan tertentu baik melalui media cetak maupun media elektronik untuk membeli makanan cepat saji (16).

\section{Menganalisis Frekuensi Konsumsi Makanan Cepat Saji pada Remaja}

Kepadatan aktivitas yang sering dialami di masa sekarang, secara tidak langsung mampu menuntut manusia melakukan berbagai hal secara cepat atau instan, salah satunya yaitu pola makan. Makanan jenis fast food atau makanan cepat saji menjadi alternatif atau pilihan terbaik bagi beberapa banyak orang, selain karena penyajiannya yang cepat dan praktis, 
mereka juga menawarkan variasi menu yang menarik. Fast food adalah jenis makanan readyto-eat-food (13).

Usia remaja merupakan fase dimana para remaja banyak melakukan aktivitas baik di sekolah maupun luar sekolah, seperti les, ekstrakulikuler, perlombaan atau olimpiade dan lain sebagainya. Hal tersebut menuntut para remaja untuk mendapatkan asupan makanan yang lebih. Tingginya aktivitas remaja membuat mereka memilih menu makanan yang instan atau secara penyajian lebih cepat dan praktis, seperti makanan cepat saji (fast food).

Terjadinya masa pandemi Covid-19 membuat mayoritas masyarakat dituntut untuk bekerja atau belajar di rumah dengan melakukan aktivitas secara online. Kondisi seperti ini menyebabkan hampir seluruh kegiatan dikerjakan di rumah dan tidak jarang hal-hal seperti bosan, suntuk, atau stress dapat terjadi. Begitu pula dengan keterbatasan para remaja untuk melakukan aktivitas di luar rumah, memungkinkan untuk memesan makanan cepat saji melalui aplikasi online dengan proses yang cepat dan praktis. Selain itu, kondisi tersebut mampu menurunkan tingkat aktivitas fisik remaja.

Sesuai dengan tabel 11 dan tabel 12 menunjukkan bahwa jenis makanan cepat saji yang sering dikonsumsi remaja pada saat masa aktif sekolah ataupun selama masa pandemi adalah mie instan dan jenis gorengan. Jenis fast food yang sering dikonsumsi remaja adalah beef burger, ice cream, mi ayam, mi instan, batagor, bakso, dan sosis(22).

\section{KESIMPULAN DAN SARAN}

Mayoritas responden penelitian di SMAN 2 Surabaya berusia 16 tahun $(55,0 \%)$, mayoritas berjenis kelamin perempuan $(66,7 \%)$, mayoritas berada di kelas XI $(51,0 \%)$, dengan berat badan mayorita sekitar 40 - $50 \mathrm{~kg}$, serta mayoritas memiliki tinggi badan 150$160 \mathrm{~cm}$. Mayoritas responden memiliki uang saku per bulan sebesar Rp500.000. Berdasarkan hasil uji statistik menunjukkan bahwa adanya hubungan antara uang saku dengan tindakan mengonsumsi makanan cepat saji.

Tidak terdapat hubungan antara tingkat pengetahuan dengan tindakan mengonsumsi makanan cepat saji di SMAN 2 Surabaya tahun 2020. Pengetahuan yang tinggi belum tentu menghasilkan perilaku yang baik, begitu pula sebaliknya. Tidak terdapat hubungan antara self efficacy dengan tindakan mengonsumsi makanan cepat saji di SMAN 2 Surabaya tahun 2020.

Mayoritas responden memiliki tingkat self regulation dalam kategori sedang. Terdapat hubungan antara self regulation dengan tindakan mengonsumsi makanan cepat saji. 
Mayoritas responden mendapatkan dukungan teman yang baik, tetapi hal tersebut tidak menentukan individu tersebut tidak mengonsumsi makanan cepat saji. Hasil menunjukkan tidak terdapat hubungan antara dukungan teman sebaya dengan tindakan mengonsumsi makanan cepat saji.

Mayoritas responden di SMAN 2 Surabaya mendapatkan dukungan orangtua yang baik. Hasil menunjukkan adanya hubungan antara dukungan orangtua dengan tindakan mengonsumsi makanan cepat saji. Sehingga perlu dioptimalkan peran dari orangtua untuk mencegah terjadinya obesitas pada remaja. Pencegahan yang dapat dilakukaan yaitu dengan pengaturan menu makan anak, memantau pemberian uang saku secukupnya untuk mengindari konsumsi makanan yang tidak sehat, serta pemberian wawasan mengenai kesehatan, terutama kesehatan gizi.

Paparan informasi yang diperoleh mayoritas responden tergolong baik. Informasi tersebut dapat melalui media online maupun media offline. Hasil menunjukkan bahwa tidak ada hubungan antara paparan informasi dengan tindakan mengonsumsi makanan cepat saji

\section{DAFTAR PUSTAKA}

1. World Health Organization. Obesity and Overweight. 2018; Available from: https://www.who.int/news-room/fact-sheets/detail/obesity-and-overweight

2. Afifah, Liyana Putri., Suyatno., Aruben, Ronny., dan Kartini, A. Faktor- Faktor yang Berhubungan dengan Konsumsi Fast Food pada Remaja Obesitas di SMA Theresiana 1 Semarang Tahun 2017. Jurnal Kesehatan Masyarakat. 2017;5(4):706-13.

3. Kementrian Kesehatan RI BP dan P. Hasil Utama Riset Kesehatan Dasar 2013.

4. Praditasari JA. Asupan Lemak, Aktivitas Fisik, dan Kegemukan pada Remaja Putri di SMP Bina Insani Surabaya. Fakultas Kesehatan Masyarakat, Universitas Airlangga. Jurnal Media Gizi Indonesia. 2018;13(2):117-22.

5. Hendra C. Faktor-Faktor Risiko Terhadap Obesitas Pada Remaja di Kota Bitung. 2016;4(1):2-6.

6. Badan Pusat Statistik. Statistik Kesejahteraan Rakyat Kota Surabaya Tahun 2017.

7. Peraturan Kementiran Kesehatan RI Nomor 25 Tahun 2014. Upaya Kesehatan Anak. Kementrian Kesehatan. Jakarta;

8. Septiani, Riswanti dan Raharjo, Bambang Budi. Pola Konsumsi Makanan Cepat Saji, Aktivitas Fisik dan Faktor Keturunan Terhadap Kejadian Obesitas (Studi Kasus pada Siswa SD Negeri 01 Tonjong Kecamatan Tonjong Kebupaten Brebes). Public Health Perspective Journal. 2018;2(3):262-269.

9. Kementrian Kesehatan RI BP dan P. Hasil Utama Riset Kesehatan Dasar Tahun 2018.

10. Badjeber F. Konsumsi Makanan cepat saji sebagai Faktor 22. Risiko terjadinya Gizi Lebih pada Siswa SD Negeri 11 Manado. Universitas Sam Ratulangi Manado; 2009. 
11. Profil Kesehatan Surabaya. Pemeriksaan Obesitas Menurut Jenis Kelamin, Kecamatan, dan Puskesmas.

12. Oktaviani, Wiwied Dwi. Hubungan Kebiasaan Konsumsi Fast Food, Aktivitas Fisik, Pola Konsumsi, Karakteristik Remaja dan Orangtua dengan Indeks Massa Tubuh (IMT) (Studi Kasus pada Siswa SMA Negeri 9 Semarang tahun 2012). Jurnal Kesehatan Masyarakat. 2012;1(2):542-53.

13. Bandura, A. A Social Cognitive Theory of Personality. 1999. New York: Guilford Publications. 2020 Oktober; Available from: https://www.uky.edu/ eushe2/.../Bandura1999ARPr.pdf

14. Glanz, Kaaren. Health Behavior and Health Education 4th Edition. Theory, Research, and Practice. United Satte of America; (2008).

15. Azwar, S. Sikap Manusia: Teori dan Pengukurannya. Yogyakarta: Pustaka Pelajar; (2013).

16. Mahpolah. Faktor-faktor yang Berhubungan dengan Kebiasaan Mengonsumsi Fast Food pada Remaja SMA Kartika V-1 Balikpapan. Politeknik Kesehatan Banjarmasin; 2015.

17. Notoatmodjo, Soekidjo. Kesehatan Masyarakat Ilmu dan Seni. Jakarta: PT. Rineka Cipta; (2010).

18. Suyanto, Edy. Hubungan Pengetahuan Risiko dan Pengamatan Lingkungan dengan Perilaku Menurunkan Berat Badan pada Remaja Berat Badan Lebih. J Keperwatan. 2016;9(1):13-17.

19. Bandura, A. Social Foundation of Thought and Action: A Social Cognitive Theory. Englewood Chlifft (Internet). 1986. (2020 Aug 5); Available from: https://www.uky.edu/ eushe2/.../Bandura1999AJSP.pdf

20. Sari, Dewi L. Analisis Faktor Risiko Tindakan Seksual Pranikah Remaja di SMA "X" Kabupaten Probolinggo (Aplikasi Social Cognitive Theory). (Surabaya): Universitas Airlangga; 2019.

21. Khomsan, Ali. Pangan dan Gizi Untuk Kesehatan. Jakarta: Rajawali Sport; (2003).

22. Kurdanti W. Faktor-Faktor yang Mempengaruhi Kejadian Obesitas pada Remaja. 2015 Apr;11(4):179-90.

23. Wulandari S. Faktor yang Berhubungan dengan Kejadian Obesitas pada Remaja di SMA Negeri 4 Kendari Tahun 2016. Universitas Halu Oleo; 2016. 